\title{
PENGARUH PENDIDIKAN MATEMATIKA REALISTIK BERBANTUAN LKS TERHADAP HASIL BELAJAR MATEMATIKA DITINJAU DARI MOTIVASI BELAJAR SISWA KELAS $V$ SD GUGUS 2 KECAMATAN BAJAWA KABUPATEN NGADA-FLORES
}

\author{
Wilibaldus Bhoke ${ }^{1}$ \\ ${ }^{1)}$ Dosen Program Studi Pendidikan Matematika STKIP Citra Bakti \\ email: wilibaldusbhoke87@gmail.com
}

\begin{abstract}
ABSTRAK
Tujuan penelitian adalah untuk mengetahui pengaruh pendidikan matematika realistik berbantuan LKS terhadap hasil belajar matematika ditinjau dari motivasi belajar siswa. Jenis penelitian ini adalah penelitian eksperimen semu (quasi eksperimen) dengan menggunakan dasain faktorial $2 \times 2$. Populasi dalam penelitian ini adalah seluruh siswa kelas V SD Gugus 2 Kecamatan Bajawa Kabupaten Ngada-Flores, dengan anggota sampel sebanyak 80 siswa. Pengambilan sampel dalam penelitian ini menggunakan teknik random sampling terhadap kelas. Data yang dikumpulkan ada dua yaitu angket motivasi dan instrumen pilihan ganda. Analisis data menggunakan analisis varians dua jalur dan dilanjutkan dengan uji Tukey. Hasil penelitian menunjukan bahwa: 1) hasil belajar matematika siswa yang mengikuti pendidikan matematika realistik lebih tinggi daripada hasil belajar matematika siswa yang mengikuti pembelajaran konvensional $\left.\left(F_{A}=2,95, p<0,05\right) ; 2\right)$ terdapat interaksi antara pembelajaran dan motivasi balajar terhadap hasil belajar matematika $\left(\mathrm{F}_{\mathrm{AB}}=\right.$ $3,132, p<0,05)$; 3) Bagi siswa yang memiliki motivasi belajar tinggi, hasil belajar matematika siswa yang mengikuti pendidikan matematika realistik lebih tinggi daripada hasil belajar matematika siswa yang mengikuti pembelajaran konvensional $\left(Q_{\text {hitung }}=4,61\right.$ dan $\left.Q_{\text {tabel }} 5 \%=3,96, Q_{\text {hitung }}>Q_{\text {tabel }}\right)$; 4) Bagi siswa yang memiliki motivasi belajar rendah, hasil belajar matematika siswa yang mengikuti pembelajaran konvensional lebih tinggi daripada hasil belajar matematika siswa yang mengikuti pendidikan matematika realistik ( $Q_{\text {Hitung }}=5,76$ dan $\left.Q_{\text {tabel }} 5 \%=3,96, Q_{\text {hitung }}>Q_{\text {tabel }}\right)$.
\end{abstract}

Kata kunci: Hasil belajar matematika, motivasi belajar, Pendidikan Matematika Realistik

\begin{abstract}
The present study examines the effect of realistic mathematics education using students' work sheet $(L K S)$ on mathematics achievement viewed from students' learning motivation. The study was quasi experimental by using $2 \times 2$ factorial design. The population in this study was the fifth grade primary school students of cluster 2 from Bajawa sub-district, Ngada regency, Flores. Samples in this study were 80 students which were chosen randomly. There were two collected data; motivational questionnaires and multiple choice instruments. Data were analyzed by using double stripe variant analysis and continued with Tukey test. The result of study showed that: 1) mathematics achievement of students following realistic mathematics education was better than the students following conventional learning $\left.\left(F_{A}=2,95, p<0,05\right) ; 2\right)$ there was an interaction between learning and learning motivation on mathematics achievement $\left.\left(F_{A B}=3,13, p<0,05\right) ; 3\right)$ to the students having higher learning motivation, mathematics achievement of students following realistic mathematics education was higher than mathematics achievement of students following conventional learning $\left(Q_{\text {observed }}=4,61\right.$ dan $\left.\left.Q_{\text {table }} 5 \%=3,96, Q_{\text {observed }}>Q_{\text {table }}\right) ; 4\right)$ to the students having lower learning motivation, mathematics achievement of students following conventional learning was higher than mathematic achievement of students
\end{abstract}


following realistic mathematics education $\left(Q_{\text {observed }}=5,76\right.$ dan $Q_{\text {table }} 5 \%=3,96$, $\left.\mathrm{Q}_{\text {observed }}>\mathrm{Q}_{\text {table }}\right)$.

Key words: Mathematics achievement, learning motivation, Realistic Mathematics Education

\section{PENDAHULUAN}

Usaha untuk meningkatkan kualitas Sumber Daya Manusia (SDM) merupakan hal yang sangat penting dan harus dilakukan secara terencana, terarah, intensif, efektif dan efisien. Pendidikan merupakan salah satu faktor yang berperan penting dalam mempersiapkan Sumber Daya Manusia (SDM) yang berkualitas sesuai dengan tuntutan persaingan global. Akhir-akhir ini semakin banyak bermunculan isu-isu yang berkaitan dengan rendahnya mutu pendidikan di Indonesia. Masalah ini di rasa semakin meresahkan, karena banyak pihak-pihak pelaksana di dalam pendidikan hanya berorientasi pada penyelesaian program pembelajaran. Hal ini tentu berdampak pada tidak optimalnya usaha untuk mencerdaskan kehidupan bangsa. Dalam beberapa riset internasional yaitu Programe for International Student Assessment (PISA) dan The Third International Mathematics and

\section{Science Study}

(TIMSS)

menjelaskan bahwa Indonesia saat ini mengalami krisis pendidikan dengan hasil pendidikan yang konsisten berada di peringkat bawah, khususnya di bidang matematika, sains, dan membaca (Kompas, 2013).

Upaya untuk meningkatkan mutu pendidikan di Indonesia telah lama dilakukan. Berbagai inovasi dan program pembelajaran telah dilaksanakan pemerintah guna meningkatkan mutu pendidikan seperti: 1) perubahan kurikulum, 2) berbagai program pelatihan penyusunan rencana pelaksanaan pembelajaran, 3) program musyawarah guru mata pelajaran (MGMP), 4) program sertifikasi guru dan dosen, 5) perbaikan sarana dan prasarana pendidikan.

Pada dasarnya upaya di atas adalah untuk menciptakan proses pembelajaran dan hasil belajar yang optimal bagi pebelajar (siswa). Proses pembelajaran sangat penting keberadaaanya dalam upaya mencapai tujuan 


\begin{tabular}{lll}
\hline pendidikan yang sebenarnya & maupun bidang lain dalam \\
dalam wujud hasil belajar. Dalam & kehidupan sehari-hari. Sejalan \\
hal ini terjadi interaksi antara & dengan itu, PERMENDIKNAS \\
siswa, guru, dan lingkungannya. & nomor 22 tahun 2006 tentang \\
Peran guru dalam mengajar sangat & Standar Isi Mata Pelajaran \\
penting. Kemungkinan kegagalan & Matematika menyebutkan bahwa \\
guru dalam menyampaikan suatu & mata pelajaran matematika \\
pokok bahasan disebabkan pada & bertujuan agar peserta didik \\
saat proses belajar mengajar guru & memiliki kemampuan sebagai \\
kurang membangkitkan perhatian & berikut. (1) memahami konsep \\
dan aktivitas siswa dalam & matematika, menjelaskan \\
mengikuti pelajaran. & keterkaitan antarkonsep dan \\
Matematika merupakan ilmu & mengaplikasikan konsep atau \\
yang bersifat universal yang & algoritma, secara luwes, akurat, \\
mendasari perkembangan IPTEK. & efisien, dan tepat, dalam \\
Matematika merupakan salah satu & pemecahan masalah, (2)
\end{tabular}
bidang studi yang menduduki peran penting dalam pendidikan. Hudojo (2005) matematika adalah alat untuk mengembangkan cara berfikir, karena itu matematika sangat diperlukan, baik untuk kehidupan sehari-hari maupun dalam menghadapi kemajuan IPTEK. Suherman (2003) menyatakan bahwa tujuan pembelajaran matematika adalah terbentuknya kemampuan bernalar pada siswa yang tercermin melalui kemampuan berpikir kritis, logis, sistematis, dan memiliki sifat obyektif, jujur, disiplin, dalam memecahkan suatu permasalahan baik dalam bidang matematika menggunakan penalaran pada pola dan sifat, melakukan manipulasi matematika dalam membuat generalisasi, menyusun bukti, atau menjelaskan gagasan dan pernyataan matematika, (3) memecahkan masalah yang meliputi kemampuan memahami masalah, merancang model matematika, menyelesaikan model dan menafsirkan solusi yang diperoleh, (4) mengomunikasikan gagasan dengan simbol, tabel, diagram, atau media lain untuk memperjelas keadaan atau masalah, (5) Memiliki sikap menghargai kegunaan matematika dalam kehidupan, yaitu memiliki 
rasa ingin tahu, perhatian, dan minat dalam mempelajari matematika, serta sikap ulet dan percaya diri dalam pemecahan masalah (Depdiknas, 2006). Mata pelajaran matematika harus dirancang tidak hanya untuk mempersiapkan siswa melanjutkan ke pendidikan yang lebih tinggi tetapi juga untuk memasuki dunia kerja. Upaya-upaya guru dalam mendesain pembelajaran merupakan bagian penting dalam keberhasilan siswa demi mencapai tujuan yang direncanakan, karena itu pemilihan metode, strategi, dan pendekatan dalam pembelajaran guna tercapainya iklim pembelajaran aktif yang bermakna adalah tuntutan yang harus dipenuhi oleh para guru.

Pengalaman di sekolah, biasanya siswa yang kurang berminat belajar matematika dikarenakan mereka mengalami kesulitan dalam memahami konsep-konsep maupun rumus matematika.

Matematika mempunyai objek yang bersifat abstrak. Sifat abstrak ini menyebabkan banyak siswa mengalami kesulitan dalam matematika. Penerapan pembelajaran yang dipandang tepat yang dapat menjembatani permasalahan tersebut yaitu pendidikan matematika realistik yakni pembelajaran matematika yang berorientasi pada matematisasi pengalaman seharihari (mathematizes everyday experience) dan menerapkan matematika dalam kehidupan sehari-hari. Melihat kondisi ini, perlu ada usaha untuk memperbaiki pendidikan matematika di Indonesia. Paradigma baru pendidikan sekarang ini lebih menekankan pada peserta didik sebagai manusia yang memiliki potensi untuk belajar dan berkembang. Siswa harus aktif dalam pencarian dan pengembangan pengetahuan. Dalam proses pembelajaran matematika di kelas, guru perlu mengajukan masalah (soal) yang rill bagi siswa sesuai dengan pengalaman dan tingkat pengetahuannya sebagai pangkal tolak pembelajaran, aktif menyelesaikan masalah dengan caranya sendiri sesuai dengan skema yang dimiliki dalam pikirannya. Peran guru lebih banyak pada memotivasi dan mendorong kegiatan belajar siswa (Tarigan, 2006). 







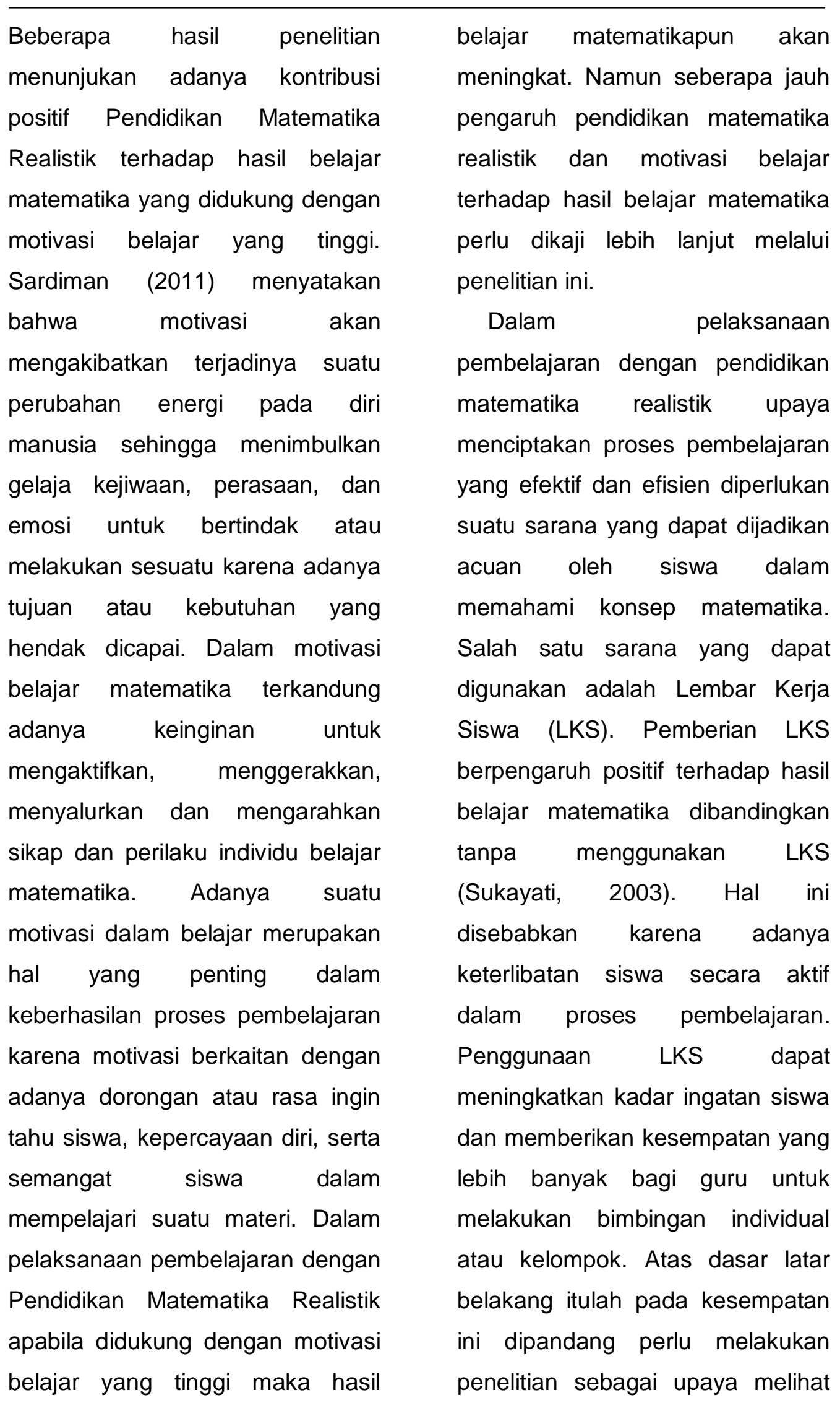


pengaruh pendidikan matematika realistik berbantuan LKS terhadap hasil belajar matematika dengan memperhatikan motivasi belajar siswa. Dengan demikian, peneliti memilih judul: "Pengaruh Pendidikan Matematika Realistik Berbantuan LKS Terhadap Hasil Belajar Matematika Ditinjau dari Motivasi Belajar Siswa Kelas V SD Gugus 2 Kecamatan Bajawa Kabupaten Ngada-Flores".

Hudojo (2005) menyatakan bahwa orientasi pembelajaran matematika di sekolah dasar atau di tingkat pendidikan dasar adalah agar siswa memahami konsep matematika, menjelaskan keterkaitan antar konsep dan mengaplikasikan konsep atau algoritma, secara luwes, akurat, efisien, dan tepat dalam pemecahan masalah. Sejalan dengan tujuan itu, siswa diharapkan dapat memahami suatu konsep matematika setelah proses pembelajaran sehingga dapat menggunakan kemampuan tersebut dalam menghadapi masalah-masalah matematika. Suherman (2003) menyatakan bahwa, matematika merupakan bahasa dan sarana berpikir secara logis dan dapat memasuki seluruh segi kehidupan manusia, dari yang paling sederhana sampai kepada yang paling kompleks. Sedangkan Hudojo (2005) menyatakan bahwa matematika berkenaan dengan gagasan berstruktur yang hubungannya diatur secara logis, bersifat abstrak, penalarannya deduktif dan dapat memasuki wilayah cabang ilmu lainnya.

Menurut teori konstruktivisme dikatakan bahwa cara yang terbaik bagi seseorang siswa untuk mempelajari sesuatu atau prinsip dalam matematika adalah dengan mengkonstruksi atau melakukan penyusunan sebagai sebuah representasi dari konsep atau prinsip tersebut (Trianto, 2008). Siswa yang berada pada jenjang pendidikan dasar atau SMP, proses belajar akan lebih baik atau melekat jika siswa yang mengkonstruksi sendiri representasi dari apa yang dipelajari tersebut.

Berdasarkan paparan di atas maka, pembelajaran konstruktivis merupakan pembelajaran yang memberikan kesempatan kepada siswa untuk mencari, memperoleh, dan mengkonstruksi sendiri pemahamannya, memperbaiki, dan mengembangkan pengetahuan 
berdasarkan pengetahuan awal siswa. Guru memiliki peranan sebagai fasilitator yang menyediakan lingkungan dan suasana belajar yang mendukung keberhasilan belajar siswa.

Berdasarkan latar belakang masalah di atas, maka masalah pokok dalam penelitian ini adalah: (1) Apakah hasil belajar matematika siswa yang mengikuti pembelajaran dengan pendidikan matematika realistik berbantuan LKS lebih baik daripada hasil belajar siswa yang mengikuti pembelajaran konvensional?

Apakah terdapat interaksi antara pembelajaran dengan motivasi terhadap hasil belajar matematika siswa? (3) Bagi siswa yang memiliki motivasi belajar tinggi, apakah hasil belajar matematika siswa yang mengikuti pembelajaran dengan pendidikan matematika realistik berbantuan LKS lebih baik daripada hasil belajar siswa yang mengikuti pembelajaran konvensional?

Bagi siswa yang memiliki motivasi belajar rendah, apakah hasil belajar matematika siswa yang mengikuti Pembelajaran Konvensional lebih baik daripada siswa yang mengikuti pembelajaran dengan pendidikan matematika realistik berbantuan LKS?

Tujuan penelitian ini adalah: (1) untuk mengetahui apakah hasil belajar matematika siswa yang mengikuti pelajaran dengan Pendidikan Matematika Realistik berbantuan LKS lebih baik daripada hasil belajar matematika siswa yang mengikuti dengan pembelajaran konvensional, Untuk mengetahui apakah terdapat Interaksi antara pembelajaran dengan motivasi terhadap hasil belajar matematika siswa, (3) Bagi siswa yang memiliki motivasi belajar tinggi, apakah hasil belajar siswa yang mengikuti pembelajaran dengan pendidikan matematika realistik berbantuan LKS lebih baik daripada hasil belajar siswa yang mengikuti pembelajaran konvensional, (4) Bagi siswa yang memiliki motivasi belajar rendah, apakah hasil belajar siswa yang mengikuti Pembelajaran Konvensional lebih baik daripada hasil belajar siswa yang mengikuti pembelajaran dengan Pendidikan Matematika Realistik berbantuan LKS. 


\section{METODE PENELITIAN}

Penelitian ini merupakan penelitian eksperimen semu (quasi eksperimen) yang mengkaji tentang pengaruh Pendidikan Matematika Realistik berbantuan LKS dengan motivasi belajar terhadap hasil belajar matematika siswa kelas V SD Gugus 2 Kecamatan Bajawa Kabupaten Ngada-Flores. Penelitian ini menggunakan rancangan penelitian Posttest-Only Control Group design, dengan rancangan faktorial $2 \times 2$.

Populasi adalah wilayah generalisasi yang terdiri atas obyek/subyek yang mempunyai kualitas dan karakteristik tertentu yang ditetapkan oleh peneliti untuk dipelajari dan kemudian ditarik kesimpulannya (Sugiyono, 2008). Populasi dalam penelitian ini meliputi seluruh siswa kelas $\mathrm{V}$ semester II (genap) SD Gugus 2 kecamatan Bajawa kabupaten Ngada-Flores yang terdiri dari 4 sekolah, yaitu SD Kisanata, SD Tanalodu, SD Ngedukelu, SDI Bajawa. Jumlah anggota populasi sebanyak 120 siswa. Sedangkan, Sampel adalah bagian dari jumlah dan karakteristik yang dimiliki oleh populasi tersebut (Sugiyono,
2008). Jumlah sampel dalam penelitian ini sebanyak 80 siswa. Pemilihan kelas dilakukan dengan teknik random sampling. Sebaran siswa pada setiap kelas dilakukan secara merata yaitu terdiri atas siswa yang memiliki kemampuan tinggi, sedang dan rendah. variabel bebas yang berupa Pendidikan Matematika Realistik Berbantuan LKS, juga mempertimbangkan variabel moderator berupa motivasi belajar siswa yang diduga ikut memberikan pengaruh variabel bebas terhadap variabel terikat.

Data yang dikumpulkan dalam penelitian ini adalah menggunakan angket dan instrumen pilihan ganda. Metode analisis data yang digunakan terdiri dari tiga bagian, yaitu: (1) analisis deskripsi data, (2) uji prasyarat terdiri dari uji normalitas, uji homogenitas, (3) uji hipotesis menggunakan Anava Dua Jalan dan uji Tukey.

\section{HASIL DAN PEMBAHASAN}

Sebelum melakukan uji hipotesis, terlebih dahulu dilakukan uji prasyarat analisis. Hasil uji normalitas menggunakan teknik Kolmogorov Smirnov (K-S), dengan bantuan program SPSS.16,0 for windows, bertujuan 
untuk meyakinkan bahwa data benar-benar berasal dari populasi yang berdistribusi normal. Teknik Komogorov Smirnov (K-S), yang diperoleh dari hasil pengolahan dengan program SPSS.16,0 for windows adalah $\mathrm{p}>0,05$ sehingga dapat dinyatakan bahwa semua data skor penelitian berdistribusi normal.

Hasil uji homogenitas menggunakan statistik Levene menunjukkan bahwa $\mathrm{p}>0,05$ untuk semua kelompok. Maka data memiliki varians yang sama atau homogen.

Untuk hipotesis pertama dalam penelitian ini adalah hasil belajar matematika siswa yang mengikuti pembelajaran dengan Pendidikan Matematika Realistik lebih baik daripada hasil belajar matematika siswa mengikuti proses pembelajaran konvensional. Berdasarkan ringkasan ANAVA dua jalur diperoleh nilai statistik $F_{\text {hitung sebesar 2,95. Pada taraf }}$ signifikansi 0,05 didapat $F_{\text {tabel }}$ sebesar 0,45 . Sehingga $H_{0}$ ditolak dan $\mathrm{H}_{1}$ diterima. Jadi, hasil belajar matematika siswa yang mengikuti Pendidikan Matematika Realistik berbantuan LKS lebih baik dari pada hasil belajar siswa yang mengikuti pembelajaran konvensional. Hal ini terjadi karena Pendidikan matematika realistik merupakan suatu pembelajaran matematika yang dilaksanakan dengan menempatkan masalah realistik dan pengalaman siswa sebagai titik awal pembelajaran sebagai sumber munculnya konsep-konsep matematika atau pengetahuan matematika formal. Sehingga dengan bertitik tolak pada sumber belajar yang bersifat realistik siswa akan lebih mudah mencapai suatu konsep yang diharapkan. Selanjutnya siswa diberikan kesempatan untuk memecahkan masalah dengan cara-cara informal, kemudian melalui matematisasi horizontal dan vertikal siswa diberi kesempatan menemukan dan mengkonstruksi konsep-konsep matematika tersebut.

Hipotesis kedua dalam penelitian ini adalah terdapat interaksi antara pembelajaran dan motivasi belajar siswa terhadap hasil belajar. Hasil uji hipotesis dengan ANAVA dua jalur diperoleh

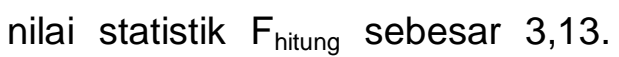
Pada taraf signifikansi 0,05 didapat $F_{\text {tabel }}$ sebesar 0,49 . Sehingga $H_{0}$ ditolak dan $\mathrm{H}_{1}$ di terima. Jadi, 


\begin{tabular}{ll}
\hline terdapat interaksi antara & dan motivasi terhadap hasil belajar \\
pembelajaran dan motivasi belajar & matematika disajikan pada gambar \\
terhadap hasil belajar matematika. & 4.7 berikut.
\end{tabular}

Profil interaksi antara pembelajaran



Gambar 4.7 Profil interaki antara Pembelajaran dan motivasi terhadap hasil belajar matematika

Berdasarkan Gambar 4.7 tampak perbedaan nilai rata-rata hasil belajar matematika untuk setiap tingkat motivasi. Untuk tingkat motivasi belajar tinggi, rata-rata hasil belajar matematika siswa yang mengikuti pembelajaran dengan Pendidikan Matemtika Realisik berbantuan LKS lebih baik daripada hasil belajar matematika siswa yang mengikuti Pembelajaran Konvensonal.
Sementara untuk tingkat motivasi belajar rendah, rata-rata hasil belajar matematika siswa yang mengikuti Pembelajaran Konvensional lebih baik daripada hasil belajar matematika siswa yang mengikuti pembelajaran dengan Pendidikan Matematika Realistik Berbantuan LKS.

Hipotesis ketiga dalam penelitian ini adalah hasil belajar matematika siswa 
yang mengikuti Pendidikan

Matematika Realistik berbantuan LKS lebih baik daripada hasil belajar matematika siswa yang mengikuti pembelajaran konvensional, untuk siswa yang memiliki motivasi belajar tinggi. Hipotesis yang akan diuji adalah rata-rata skor hasil belajar matematika untuk kelompok siswa yang memiliki motivasi belajar tinggi siswa yang mengikuti
Pendidikan Matematika Realistik berbantuan LKS (A1B1) adalah sebesar 17,75. Rata-rata skor hasil belajar matematika untuk siswa yang memiliki motivasi belajar tinggi siswa yang mengikuti pembelajaran konvensional (A2B1) adalah sebesar 14,95 , sedangkan rata-rata jumlah kuadrat dalam (RJKD) adalah sebesar 7,36. Selanjutnya, perhitungan uji Tukey dapat dilakukan dengan rumus:

$$
\mathrm{Q}=\frac{A_{1} B_{1}-A_{2} B_{1}}{\sqrt{\frac{R K D}{n}}}=\frac{17,750-14,950}{\sqrt{\frac{7,362}{20}}}=\frac{2,8}{\sqrt{0,3681}}=\frac{2,8}{0,606712452}=4,615036317=4,61
$$

Hasil perhitungan dengan $U j i$ Tukey menunjukan nilai $Q$ hitung sebesar 4,61, sedangkan nilai $Q$ tabel pada taraf signifikansi 0,05 sebesar 2,86 . Ini menunjukan nilai $Q_{\text {hitung }}>Q_{\text {tabel }}$ pada taraf $5 \%$ sehingga $H_{0}$ ditolak dan $H_{1}$ diterima. Jadi kesimpulannya untuk siswa yang memiliki motivasi belajar tinggi, hasil belajar matematika siswa yang mengikuti pembelajaran dengan Pendidikan Matematika Realistik lebih baik daripada hasil belajar matematika siswa yang mengikuti Pembelajaran Konvensional. Hasil perhitungan dengan Uji Tukey dapat dilihat pada tabel $4.18 \mathrm{di}$ bawah ini.

Tabel 4.18 Hasil Uji Tukey Untuk Siswa yang Memiliki Motivasi Belajar Tinggi

\begin{tabular}{|c|c|c|c|c|}
\hline Jenis asesmen & $\begin{array}{c}\text { Pendidikan } \\
\text { Matematika } \\
\text { Realistik } \\
\text { berbantuan LKS }\end{array}$ & $\begin{array}{c}\text { Pembelajaran } \\
\text { Konvensional }\end{array}$ & $\mathbf{Q}_{\text {hitung }}$ & $\begin{array}{c}\mathbf{Q} \\
\text { tabel } \\
\%\end{array}$ \\
\hline Rata-rata & 17,750 & 14,950 & 4,61 & 2,86 \\
\hline RJKD & \multicolumn{2}{|c|}{7,362} & \\
\hline DB & \multicolumn{2}{|r|}{81} & \\
\hline
\end{tabular}




\begin{aligned} \hline Hipotesis keempat dalam & Pendidikan Matematika Realistik \\ penelitian ini adalah hasil belajar & (A1B2) adalah sebesar 17,500. \\ matematika siswa yang mengikuti & Rata-rata skor hasil belajar \\ Pembelajaran Konvensional lebih & matematika untuk siswa yang \\ baik daripada hasil belajar & memiliki motivasi belajar rendah \\ matematika siswa yang mengikuti & untuk siswa yang mengikuti \\ pembelajaran Pendidikan & pembelajaran konvensional (A2B2) \\ $\begin{array}{l}\text { Matematika Realistik berbantuan } \\ \text { LKS, pada siswa yang memiliki }\end{array} &$ adalah sebesar 14,100, sedangkan \\ motivasi belajar rendah. Rata-rata & (RJKd) adalah sebesar 7,362. \\ skor hasil belajar matematika untuk & Selanjutnya perhitungan uji Tukey \\ siswa yang memiliki motivasi & dapat dilakukan dengan rumus: \end{aligned}
belajar rendah untuk siswa yang mengikuti

$$
\mathrm{Q}=\frac{A_{1} B_{2}-A_{2} B_{2}}{\sqrt{\frac{R K D}{n}}}=\frac{17,500-14,100}{\sqrt{\frac{7,362}{20}}}=\frac{3,4}{\sqrt{0,3681}}=\frac{3,4}{0,606712452}=5,603972671=
$$

5,60

Hasil perhitungan dengan uji Tukey diperoleh nilai $Q_{\text {hitung }}$ sebesar 5,60 , sedangkan nilai $Q_{\text {tabel }}$ pada taraf signifikansi 0,05 sebesar 2,86. Ini menunjukan nilai $Q_{\text {hitung }}>Q_{\text {tabel }}$ pada taraf $5 \%$ sehingga $H_{O}$ ditolak $\mathrm{H}_{1}$ diterima. Jadi kesimpulannya untuk siswa yang memiliki motivasi rendah, hasil belajar matematika siswa yang mengikuti Pembelajaran Konvensonal lebih baik daripada hasil belajar matematika siswa yang mengikuti pembelajaran Pendidikan Matematika Realistik berbantuan LKS. Hasil perhitungan dengan Uji Tukey dapat dilihat pada tabel 4.19 dibawah ini. 
Tabel 4.19 Hasil Uji Tukey untuk siswa yang memiliki motivasi belajar rendah

\begin{tabular}{|l|l|c|l|l|}
\hline Jenis asesmen & $\begin{array}{l}\text { Pendidikan } \\
\text { Matematika } \\
\text { Realistik } \\
\text { berbantuan } \\
\text { LKS }\end{array}$ & $\begin{array}{l}\text { Pembelajaran } \\
\text { Konvensional }\end{array}$ & $\begin{array}{l}\mathbf{Q} \\
\text { hitung }\end{array}$ & $\begin{array}{l}\mathbf{Q} \\
\text { tabel } \\
\mathbf{5} \%\end{array}$ \\
\hline Rata-rata & 14,100 & 17,500 & 5,60 & 2,86 \\
\hline RJKD & \multicolumn{3}{|c|}{8,362} & \\
\hline DB & \multicolumn{3}{|c|}{} \\
\hline
\end{tabular}

Penelitian ini didukung oleh penelitian yang sebelumnya dilakukan oleh para peneliti berikut ini: (1) Arif Q. R, Nedin B, Saur M. T (2012) yang berjudul hubungan antara motivasi berprestasi dengan hasil belajar mata pelajaran matematika, menemukan bahwa terdapat kontribusi motivasi belajar dalam peningkatan hasil belajar mata pelajaran matematika sebesar 11,85\% merupakan kontribusi yang cukup besar, (2) Supardi U.S (2012) dalam penelitiannya berjudul pengaruh pembelajaran matematika realistik terhadap Hasil belajar matematika ditinjau dari motivasi belajar menunjukan: (1) hasil belajar siswa yang diajar dengan menggunakan RME lebih tinggi daripada hasil belajar matematika siswa yang diajar secara konvensional; (2) terdapat interaksi antara pembelajaran dan motivasi belajar terhadap hasil belajar, (3) Angriani T, N.K. Antou, M. Lasut (2012) dengan judul penelitiannya

hubungan Motivasi Berprestasi dengan Hasil Belajar Matematika Siswa Kelas XI IPA SMA Negeri 1 Langowan, pada hasil penelitiannya menunjukan bahwa, terdapat hubungan yang signifikan dengan tingkat hubungan sangat kuat antara motivasi berprestasi dan hasil belajar matematika siswa dengan koefisien korelasi $r=$ 0.805 .

\section{PENUTUP}

Simpulan dalam penelitian ini adalah sebagai berikut.

(1) hasil belajar matematika siswa yang mengikuti pembelajaran Pendidikan Matematika Realistik berbantuan LKS lebih baik daripada hasil belajar matematika siswa yang mengikuti Pembelajaran Konvensional; 
(2) terdapat interaksi antara pembelajaran dan motivasi belajar terhadap hasil belajar matematika siswa;

(3) hasil belajar matematika siswa yang mengikuti pembelajaran Pendidikan Matematika Realistik Berbantuan LKS lebih baik daripada hasil belajar matematika siswa yang mengikuti Pembelajaran Konvensional, pada siswa yang memiliki motivasi belajar tinggi.

(4) untuk siswa yang memiliki motivasi belajar rendah, hasil belajar matematika siswa yang mengikuti Pembelajaran Konvensional lebih baik daripada hasil belajar matematika siswa yang mengikuti pembelajaran dengan Pendidikan Matematika Realistik Berbantuan LKS, pada siswa yang memiliki motivasi belajar rendah. Dengan demikian dapat disimpulkan bahwa, Pendidikan Matematika Realistik Berbantuan LKS dan motivasi belajar yang dimiliki siswa mempunyai pengaruh yang signifikan terhadap hasil belajar matematika terutama pada siswa kelas V SD Gugus 2 Kecamatan Bajawa Kabupaten Ngada-Flores.

\section{DAFTAR PUSTAKA}

Depdiknas. 2006. Kurikulum

Tingkat Satuan Pendidikan. Depdiknas. Jakarta.

Hamdu, G. \& Agustina, L. 2011. Pengaruh Motivasi Belajar Siswa terhadap Prestasi Belajar IPA di Sekolah Dasar (Studi Kasus terhadap Siswa Kelas IV SDN Tarumanagara Kecamatan Tawang Kota Tasikmalaya. Jurnal Penelitian Pendidikan. Vol. 12 No. 1. ISSN 1412-565X.

Hadi, S. 2005. Pendidikan Matematika Realistik dan Implementasinya. Banjarmasin: Tulip.

Hudojo, H. 2005. Pengembangan Kurikulum dan Pembelajaran Matematika. Malang: UM Press.

Kompas, 2013. Indonesia Alami Krisis Pendidikan: Jakarta. Diakses tanggal 18 juni 2013

Sugiyono. 2008. Statistika Untuk Penelitian. Bandung: Alfabeta

Sukayati. 2004."Model-Model Pembelajaran Matematika di Sekolah Dasar". Tersedia pada:

http://p4tkmatematika. Org/ downloads/ sd/ Model Pembelajaran.pdf. (diakses tanggal 5 februari 2014)

Tarigan, D. 2006. Pembelajaran Matematika Realistik. Jakarta: Depdiknas. 